\title{
Granitkirker i Jylland og Angel
}

Romansk stenhuggerkunst

\section{Af Otto Norn}

I forordet til sin ypperlige oversigt Vore Landsbykirker ${ }^{1}$ skriver forfatteren, Nationalmuseets mangeårige leder, historikeren og arkæologen M. Mackeprang: „Vore Domkirker kan ikke staa Maal med den store Verdens, hvorfra deres Idéer er komne, ofte som halvvejs Kopier «, og denne vurdering er ligeså rigtig som tilføjelsen vedrørende de små landsbykirker, nemlig at det nationale $i$ langt højere grad fremtræder i disse. Ikke så få har tilmed været af en kunstnerisk kvalitet helt på højde med, hvad man kan konstatere $\mathrm{i}$ de gamle europæiske kulturlande.

Siden fremkomsten af Mackeprangs bog har arkæologer og kunsthistorikere flittigt forsket både $\mathrm{i}$ domkirker og landsbykirker, især ved den til Nationalmuseet knyttede, af Mackeprang i 1933 grundlagte udgivervirksomhed Danmarks Kirker, hvis medarbejdere burde skænke nationen en 3., revideret udgave af Vore Landsbykirker. Dette ønske fremsættes vel vidende om stabens krævende opgave: at undersøge og beskrive landets gamle kirkebygninger og inventar amt for amt. I 1963 blev Sønderjylland afsluttet, og nu er Danmarks Kirker kommet til Ribe amt, hvoraf nylig er udsendt de to første hefter. ${ }^{2}$ Her har redaktøren, arkitet Elna Møller behandlet Ribe domkirkes bygning i romansk tid. Da det ikke er så længe siden, at Dietrich Ellger på tilsvarende måde publicerede Slesvig domkirke, ${ }^{3}$ kan der være flere grunde til at se lidt nærmere på Valdemarstidens domkirkebyggeri, ikke blot $\mathrm{i}$ det sydvestjyske og slesvigske stift, men også i det nørrejyske Viborg, hvor Jens Vellev ${ }^{4}$ har nye undersøgelser i gang, og i ærkestiftet Lund, hvis domkirke i årene 1954-1963 blev grundigt undersøgt af Erik Cinthio og istandsat af Eiler Græbe. Yderligere anledning til at beskæftige sig med 1100årenes omfattende kirkebyggeri giver Jane Bossens og Helge Krempins billedbog: Granit i Angel. ${ }^{6}$ Denne meget prydelige publikation omhandler en gruppe kvaderstenskirker og granitfonte, der har tilknytning til Slesvig domkirke.

$\mathrm{Nu}$ hænger det ganske vist ikke sådan sammen, at landsbykirkernes arkitektur til enhver tid og alle steder lader sig forstå ud fra kendskab til stiftskirkernes, på den anden side kan det ikke overraske, at der fra et stort byggeværksted ved en domkirke nu og da må være udgået kunstneriske impulser til mange landsogne. I adskillige tilfælde kan man konstatere 
resultatet af en sådan påvirkning og derfor ikke undgå at spekulere over, hvorpå forholdet har beroet. Her vil faktorer som finansiering, organisation, materiale og teknik først og fremmest komme i betragtning. Da samtiden kun har efterladt meget få og yderst kortfattede skriftlige oplysninger om det storslåede kirkebyggeri i ældre middelalder, er kunsthistorikeren henvist til at "aflæse" bygningerne og jæunføre sine resultater med den smule viden, der er at hente i de gamle skrifter. Det er nytteløst at ærgre sig over, at den i øvrigt så veltalende Saxo ikke har fundet det umagen værd i sin krønike at nævne, hvorledes det gik til, at der i hans tid kunne stå hundreder af større og mindre stenkirker under opførelse.

De årstal, som direkte lader sig knytte til rejsningen af vore domkirker, er hurtigt opregnet. For Lundekatedralens vedkommende er i ærkebispesædets mindebøger næunt årstallene for nogle alterindvielser, hvoraf med sikkerhed kan sluttes, at det store byggeri er blevet påbegyndt kort tid efter ærkesædets oprettelse i 1104, og at domkirkens kor har kunnet tages i brug ved midten af århundredet. Om vestpartiet forlyder intet, men arkæologiske iagttagelser tyder på, at byggeriet har været sat igang omtrent samtidigt i øst og vest. Helt færdig har Lunds domkirke næppe været før sent i århundredet.

Om Viborg domkirkes opførelse foreligger ingen skriftlig overlevering. I Hellig Kjelds levnedsbeskrivelse, forfattet i sidste halvdel af 1100 'erne, nævnes et par begivenheder, som historikerne i mangel af direkte information har benyttet til datering af den i slutningen af forrige århundrede næsten totalt fornyede bygning. 1133 blev biskop Eskil myrdet i S. Margrethes kirke i Asmild, som kunne tænkes temporært at have været stiftets bispesæde, ja måske den romanske granitkirkes forløber, og i 1150, kort før sin død, lod den syge Kjeld sig bringe over i domkirkens kor, som formodes at have været granitkirkens, da færdigt og taget $i$ brug. Bevarede bygningsdele, notater og opmålinger viser, at de to vesttårnes øvre partier først kan være rejst et par årtier ind i 1200 'erne.

Hvad angår en historisk dokumenteret datering af Slesvig domkirke, er vi ligeså ilde farne. Ganske vist oplyser Saxo og Knytlinge Saga, at kong Niels år 1134 blev myrdet "in aedem Petri «; men heraf kan ikke med sikkerhed sluttes, at udsagnet gælder den fladloftede pillebasilika, af hvilken kun spredte rester er synlige, indkapslet i den nuværende bygning, der $i$ hovedsagen har præg af at være en gotisk halkirke.

Angånde Ribe domkirkes alder har drøftelserne været lange og livlige, for de historiske begivenheders vedkommende afhængige af den kortfattede og ikke direkte overleverede bispekrønike, som er nedskrevet o. 1230. Navnlig to af dens optegnelser er af arkæologisk interesse. Den ene gælder biskop Thure, faldet 1134 i slaget ved Fodevig, om hvem meddeles, at han var den 
første, som begyndte at lægge grunden til Ribe kirke med stentavleværk ("qui ecclesiam Ripensem primus fundare coepit lapideo tabulatu«). Den anden meddeler, at under biskop Stefan, d. 1177, skal Ribe domkirke være blevet ødelagt ved en brand, tilmed "en dobbelt « sådan, "quia ecclesia cum claustro duplici incendio est uastata «. Ifølge en senere tilføjelse skulle branden have fundet sted 1. oktober 1176 og have ødelagt en stor del af byen og domkirken med alle dens skatte, bl.a. skrinet med biskop Liufdags ben, som af biskop Radulf, d. 1171, var stillet på alteret i den hensigt at få bispestolens første indehaver anerkendt som helgen. At skaffe sig en helgen var tidens ambition også i andre danske stifter, Ringsted (Knud), Viborg (Kjeld), Århus (Niels).

Fuldført kan Ribe domkirke ikke have varet før et par årtier ind $\mathrm{i}$ 1200 'erne. Dette røber vestportalens dekorative former klart. Krøniken meddeler, at biskopperne på den tid gav kirken forskelligt løst udstyr: Omer, d. 1204, bl.a. penge til forgyldning af et alter, Tue fem korkåber.

Sammenfattende kan siges: Kort tid efter det nordiske ærkesædes oprettelse planlagde man opførelsen af nye stenkatedraler i Lund, Viborg, Ribe og Slesvig. Samtidigheden taler stærkt for den opfattelse, at disse grundlæggelser skyldes et overordnet initiativ med nationalt sigte, ved hvilket betydningen af det nye nordiske ærkebispesæde skulle markeres. I hvert enkelt tilfælde må have været lagt et byggeprogram og skabt en plan eller en model, der angav bygningens format og hoveddisposition, $\mathrm{i}$ alle fire tilfælde den fladloftede, treskibede pillebasilikas grundtype, således som denne endnu tilkendegiver sig ved opmåling af de eksisterende domkirker. Dog må hertil føjes, at man desværre kun har ringe kendskab til vore domkirkers oprindelige vestpartier, der kan have været planlagt rigt, med tårnprydede forhaller.

Nære slægtsforbindelser mellem de biskoppelige bygherrer, alle af stormandsæt, og med kongehuset har uden tvivl gavnet finansieringen og på anden vis styrket samhørigheden mellem byggepladserne.

De høvdingeætlinge og storbondesønner, som tog styret i den unge danske kirkeprovins, var særdeles velorienterede internationalt, også som byggeledere. Det skal der her nævnes to eksempler på.

I Viborg blev den i 1133 myrdede biskop Eskils efterfølger provst Svend, en broder til ærkebiskop Asser af den mægtige jydske Thrugot-slægt. Svends brodersøn var Eskil, den senere ærkebiskop. Biskop Svend, under hvis styre Viborg domkirkes mure rejste sig, drog på sine gamle dage sammen med broderen Eskil, en jysk herremand, på pilgrimsfærd til Det hellige Land, hvor de begge døde 1153 og blev begravet i Paternosterkirken på Oliebjerget i Jerusalem, til hvis genopførelse de havde skænket en del af deres gods. At 
Viborg domkirkes bygherre har bekostet genopførelsen af en af De hellige Steders kirker $i$ Jerusalem og ladet sig begrave der, er et vidnesbyrd om Romerkirkens vide vægge.

Hvor intimt kirkelederne kunne stå $i$ indbyrdes forbindelse vedrørende deres byggefinanser findes fra tiden 1189-90 et vidnesbyrd om i en henvendelse til biskop Valdemar (Knudsøn) af Slesvig, "proche parent du Roi de Danemark «, fra abbed Stefan ved Sainte-Geneviève-klostret i Paris, om subsidier til sin kirkes restaurering. ${ }^{7}$ Stefan havde som abbed været både Valdemars og den senere Roskildebiskop Peder Sunesøns læremester. Med Peder Sunesøn bevarede Stefan forbindelsen, også sidenhed som biskop i Tournai, hvilket afspejler sig i Roskilde domkirkes kor. Biskop Valdemar var, da han modtog abbed Stefans henvendelse, optaget af etableringen af et cistercienserkloster i Guldholm; fra 1192 sad han som kongens fange på Søborg, så Stefan har næppe fået stor støtte fra Slesvig.

De kongelige patronatskirker ligger gennemgående, hvad størrelse og udsmykning angår, over landsbykirkernes gennemsnit, og selv om deres stiftelsesår ikke er optegnet $\mathrm{i}$ de senere kilder, burde en samlet historiskarkæologisk vurdering af kategorien: stormandskirker, tilvejebringes. Bortset fra, at det er uvist, når tiende indførtes i Danmark, lod en stenkirke sig ikke opføre for et par års kirkeskat. Tiende var som investering langsigtet, men naturligvis rar at disponere over for den, der som stifter havde anbragt en del af sin kapital $i$ et kirkebyggeri. Det er ikke usandsynligt, at næste oversigt over Danmarks bygningskunst i 1100'erne bør begynde med landsbykirkerne og slutte med domkirkerne. At få bøtten vendt på denne måde ville virke forfriskende.

Viborg domkirkes plan er tydeligvis afhængig af Lunds. Slesvigs har sandsynligvis været det. Ribes er noget for sig selv ved (ligesom Slesvig domkirke) at mangle krypt og tillige derved, at apsisrundingen direkte slutter sig til tværskibet. Hensyn til byggepladsen, en flyvesandsklit ved bredden af Ribe ådal, kan have været bestemmende $\mathrm{i}$ begge henseender, men yderst gådefuldt er det, at man ikke fra "domkirkebyen“, syd for Ribe å har gjort fund, der er $x$ ldre end fra tiden 0.1100.

Af de oprindelige hovedtræk galder for alle de fire danske domkirker, at de er typiske for kirkerne i det "kunstlandskab", der stort set omfattede ærkebispedømmet Köln med bispedømmerne Liège og Utrecht. Man har givet området navn efter floderne Rhin-Maas. Her blomstrede den kunstneriske virksomhed kraftigt op efter en ufrugtbar periode mellem 1070 og 1130. Vore romanske domkirkers fælles grundtræk har sin naturlige forudsætning i datidens kulturgeografiske mønster. Østersøområdet, Skandinavien med dets søforbindelse til Rusland var indtil slutningen af 1100'erne spærret ude 
fra Vest- og Sydeuropa af de hedenske slaviske stammer, der langs Østersøens nordkyst havde trængt sig frem næsten til Elben. Da samtidig omsejlingen gennem Skagerak var anset for farlig, og det vestre indløb til Limfjorden sandet til i begyndelsen af 1100'erne, måtte fjernhandelen sprænge sig vej gennem den jyske halvø, hvor fjorde og floder gjorde det lettest. Hedeby og dens afløser i begyndelsen af 1100 'erne, Slesvig, fik sin store betydning for øst-vest-handelen, men også som knudepunkt på den nord-syd-gående landevejsforbindelse Hærvejen, der under betegnelsen "Der Hellweg" fortsatte gennem Sachsen, overskred Weserfloden ved Corvey og førte videre gennem Vestfalen, hvis handel blomstrede vældigt op i tiden efter 1150. I Soest eksisterer endnu Slesvigfarernes kapel, en fin lille bygning fra slutningen af 1100 'erne. I Slesvig ved Danmarks sydgrænse stod Østersøen gennem Slien og Trene $i$ forbindelse med de floder, som skar sig dybt ind $i$ kontinentet, Rhinen fremfor alle. Ribe, Slesvigs arvtager, var endvidere udgangspunkt for Danmarks "Vestervegr«, sejlruten til England, Spanien, Middelhavsområdet og Det nære Østen, hermed nordiske korsfareres og pilgrimmes udskibningshavn.

Det er velkendt, at vi i kirkebygningerne, både i deres byggematerialer og i de former, som bygmestre og billedkunstnere gav dette materiale, har tydelige vidnesbyrd om Slesvig domkirkes slægtskab med de øvrige danske. Dette er umiddelbart at kende, når man står foran kirkens hovedindgang Petersportalen. Endnu tydeligere fremtræder de nationale stiltræk i de granitkirker, som Jane Bossen og Helge Krempin har publiceret, og som senere skal blive omtalt.

Sålænge forskningen har beskæftiget sig med middelalderens kirkebyggeri, d.v.s. $\mathrm{i}$ de sidste 150 år, har dens metode været at kombinere historiens litterære og arkæologiens materielle udsagn. Medens de skriftlige kilder stort set er de gammelkendte, er de arkæologiske stadig blevet forøget, især ved de seneste års udgravninger under stenkirkernes gulve. Herved er indsamlet værdifulde oplysninger om de ældre trækirker, hvoraf tidligere kun få levn var kendt.

Skønt man kan gå ud fra, at der allerede i slutningen af 9. århundrede var trækirker både i Hedeby, Slesvig og Ribe, findes næppe den mindste splint tilbage af disse danske urkirkebygninger, der, hvor interessante de end må have været, heller ikke ville have videre interesse i denne sammenhæng, ihvertfald ikke direkte. Men helt kan man ikke se bort fra forgængerne, når hensigten er at belyse stenkatedralernes bygningshistorie. Både i Lund, Viborg, Ribe og Slesvig har arkæologerne meget energisk ledt efter spor og rester af de ældre og ældste domkirker, med vekslende held.

Heldigst har Erik Cinthio været i Lund, hvor den biskoppelige kirke, til 
hvis opførelse Knud den Hellige i 1085 skænkede rige gaver, lod sig afsløre som en forholdsvis lille og enkel, énskibet stenbygning med kor af kvadratisk plan. Den fungerede kun et halvt hundrede år, indtil man o. 1150 kunne tage den store, nye ærkebiskoppelige kirkes kor i brug. I Viborg skjuler granitkatedralens forgænger sig stædigt under jorden, hvis den ikke som foreslået skal søges i Asmild hinsides søen. De rester af et retkantet kor med halvcirkulær apsis, som A. Kamphausen i 1955 undersegte under Slesvig domkirkes gotiske kor, kan ikke være levn af en bygning ældre end den af granitkvadre og tuf $i$ begyndelsen af 1100 'erne opførte, og fundet bestyrker opfattelsen af dennes samhørighed med søsterkirkerne i kongeriget.

I Ribe, hvor man som tidligere næunt, har krønikens oplysninger om biskop Thures initiativ for at rejse en kirke af murværk af stentavl, er problemet om denne bygnings mulige tilstedeværelse i det endnu stående murvark atter blevet aktuelt ved Danmarks Kirkers nye undersøgelser og forsøg på en nøjere datering af den romanske bygning, og da Elna Møller på dette spændende punkt i diskussionen om Ribe domkirkes bygningshistorie er kommet til et andet standpunkt end sine forgængere, J. Helms, F. Beckett og M. Mackeprang, findes en rimelig grund til at se lidt nøjere på argumentationen i Danmarks Kirker. Jacob Helms, der efter mange års indgående studier af Ribe domkirke og dens arkitekturhistoriske relationer, 1870 nedfældet i det fremragende folioværk, blev gammel nok til at udnytte muligheden for at revidere sig selv. Anledningen gav den store bygningsrestaurering o. 1900, og resultatet blev arkitektens og arkæologens trykte redegørelse fra $1906,{ }^{8}$ hvori sidstnæunte, da 82 år gammel, gør sig til talsmand for den anskuelse, at branden af biskop Thures murværk blot kan have levnet det allernederste af bygningens østparti. Resten af den stående kirkebygning måtte Helms herefter anse for hidrørende fra slutningen af 1100 'erne. Rigtigheden af denne datering har senere forskere betvivlet udfra en stilistisk vurdering af bygningsformerne sammenlignet med tilsva rende i Rhinlandet. I Danmarks Kirker skønnes nu i 1981, at kirkens østparti må have nærmet sig fuldførelsen, da den meget omtalte brandkatastrofe indtraf, og redaktøren tager så friskt fat ved helt at fjerne "Thures kirke « fra jordens overflade, hermed også muligheden af, at der nederst i de endnu stående mure kan være indkapslet noget af Thures murværk. Måske inspireret af E. Cinthios held under jagten på Knud den Helliges domkirke i Lund, hvis rester man tidligere mente at kunne spore i den nuværendes østparti, men overraskende stødte på i langhusets nordøstre del, finder Danmarks Kirker plads til sin selvstændige "Thures kirke", en af omfang beskeden énskibet bygning, som antages at have ligget inden for afgrænsningen af den nuværende domkirkes midterskib med koret ragende ind $\mathrm{i}$ dens korsskæring. Motiveringen for den således 
foreslåede placering af den i øvrigt direkte totalt upåviselige "Thures kirke « har Danmarks Kirker fundet $i$ en iøjnefaldende anormalitet $i$ den stående domkirkes langhus, hvor fundamentet til nordre sideskibsmur har været lagt ud $i$ et niveau ca. $50 \mathrm{~cm}$ højere end søndre med den konsekvens, at man til udligning af forskellen i gulvhøjden ved afgravning og undermuring har måttet gribe til den udvej "at forlænge“, d.v.s. undermure, nordre sideskibsmur nedefter og gøre nordre midterskibsarkader $50 \mathrm{~cm}$ højere end de søndre. Denne Ribe domkirkes "skulderskævhed " og et meget lille knæk i midterskibets længdeakse er for Danmarks Kirker beviset for, at "Thures kirke « må have ligget inden i den nuværende indtil det tidspunkt, da dennes kor kunne tages $\mathrm{i}$ brug. Ved nedrivningen skulle man så have taget vare på biskopperne Odinkars, Nothulfs og Assers ben og flyttet dem til den her i det følgende omtalte nichegrav, $i$ nordøsthjørnet af den nye, under opførelse stående kirkes nordre korsarm. Ved på denne måde at skaffe sig af med de rester af Thures murværk, som J. Helms mente at kunne påvise i den nederste del af den eksiisterende domkirkes apsis, lykkes det Danmarks Kirker at nå frem til en datering af den nuværende domkirkes østafslutning og kathoveddøren, der bedre harmonerer med den almindelige stiludvikling i Rhin-Maasområdet. Men også denne nyopfattelse må naturligvis tage hensyn til bispekrønikens oplysninger om branden 1176 og de spor af denne, som de ældre arkæologer har ment at kunne eftervise på apsis, tværskib og under den romanske domkirkes højalter.

På dette punkt i bevisførelsen foreholder Danmarks Kirker læseren nogle oplysninger. Vi står idag både ude og inde spørgende overfor apsis' skalmur og nylagte kirkegulv, men vore spørgsmål preller af på det glatte murværk og blanke gulv med dets varmeriste, og disse kan give enhver gulvarkæolog kuldegysninger ved tanken om det vacuum, der findes herunder. Vi er i Ribe ikke meget bedre stillet end $i$ Viborg og indtil videre udelukkende henvist til at nyvurdere de beretninger og notater, som ældre tiders arkæologer har overladt eftertiden. Hvad angår revnerne i kathoveddørens tympanon og afskalningen på granitsøjlerne $\mathrm{i}$ nordre tværskibsarm, bliver disse af Danmarks Kirker nytolket og opfattet som resultat af forkert belastning. Søjleføddernes forvitring får jordfugten skyld for, og brandsporene under hovedalteret reduceres til vidnesbyrd om et lokalt uheld. Da spor efter en ødelæggelse, der fandt sted for 800 år siden, kan være vanskelige at bestemme netop som brandspor, burde notaterne fra de arkæologer, der så bygningen afklædt, have været kommenteret $i$ enkeltheder. Nok er dr. Ellgers skildring af Slesvig domkirkes bygningshistorie tør kost for den almindelige læser, hvad dog lader sig undskylde derved, at forfatteren har villet give læseren mulighed for selv at tage stilling til de allermest prekære arkæologiske 
problemer, f.eks. tolkningen af de apsisfundamenter, der i 50'erne kom for dagens lys og straks af A. Kamphausen blev anset for rester af en ældre bygning (Ellger, s. 94).

Det ville dog på dette punkt føre altfor vidt her at gå i enkeltheder, også selvom problemet forekommer vigtigt. Oplysningerne i bispekrøniken, hvis værdi som historisk kilde er omtvistet, har, ikke mindst hvad branden 1176 angår, utvivlsomt $i$ altfor høj grad influeret arkæologernes opfattelse af Ribe domkirkes kronologi. Det samme gælder kunsthistorikernes jæunføring af kathoveddørens tympanon med Gjellerup kirkes to, hvoraf det ene er dateret 1140 og derfor blevet taget til indtægt for den tidlige datering af Ribe domkirkes østparti. På denne måde har man forsøgt "at bevise “ tilstedeværelsen af stentavleværk fra biskop Thures tid. Hans død $1134 \mathrm{er} \mathrm{det}$ andet fatale årstal i bispekrøniken.

Stiller man sig tvivlende overfor bispekrønikens udsagn vedrørende 1176brandens omfang og kan dele Danmarks Kirkers mistro til, hvad tidligere tiders arkæologer har set, eller ment at kunne se, af brandspor i domkirkens østparti, og begge dele kan som næunt være berettiget, må heraf følge, at branden har været uden alvorlige konsekvenser for opførelsen af den romanske, endnu stående bygning. Vælger man at stole både på bispekrønikens brandhistorie og på Danmarks Kirkers hypotese om "kirken inde $\mathrm{i}$ kirken “, må det være denne, som 1176 blev ødelagt, med alle sine skatte, indbefattet biskop Liufdags ben. Disse har da vist sig ikke at være hellige, og der kan være grund til endnu engang at overveje dateringsproblemet.

Den opmærksomme læser vil forlængst have noteret sig anførselstegnene omkring "Thures kirke«, en benævnelse som yngre arkæologer og kunsthistorikere, sidst Hugo Johannsen ${ }^{9}$ ynder at bruge. Hermed skulle allerede være antydet, at Thures kirke aldrig har eksisteret, hvilken påstand lader sig begrunde uden brug af graveske.

Thure var biskop o. 1120-1134. Selv om han eventuelt havde påbegyndt sit domkirkebyggeri straks efter sin indsættelse, ville han kun have haft en ti, tolv år til at fuldføre det. Hvor beskeden han end kan have anlagt sin stenkatedral, ville den næppe have kunnet komme under sit brandbare tag inden 1134, endsige 1127, da kong Niels fejrede sin søn Magnus' bryllup i Ribe (DK, s. 115). Og hvorfor i grunden, skulle Thure i den florissante og internationalt orienterede by Ribe have demonstreret så langt ringere ambitioner end sine bispebrødre i Vibog og Slesvig og ladet sig nøje med en katedral i landsbykirkeformat?

Men bispekrøniken meddeler heller ikke, at Thure byggede Ribe kirke af stentavl, men at han begyndte at lægge grunden ("fundare" må her tages bogstaveligt) til en sådan kirke, hvilket ikke helt giver samme mening. 
Det må herefter indtil videre forekomme rimeligt fortsat at lade den punkterede linie under apsisvinduerne på planchen i Helms' folioværk fra 1870 stå for at mar̂kere, at neden for denne, bag arkitekt Ambergs forblændersten fra 1900 gemmer sig murværk fra o. 1130. Apsis' imponerende sokkel af store, veltilhugne ganitkvadre må stadig anses for at være de synlige rester af biskop Thures meget omtalte "stentavleværk “. Hvorledes det kan forholde sig med kathoveddørens berømte tympanon, skal sidenhen siges nogle ord $\mathrm{i}$ forbindelse med det vigtige problem: Den jyske granitskulpturs opkomst og eventuelle forbindelse med byggepladserne ved domkirkerne $\mathrm{i}$ Viborg, Ribe og Slesvig. Men forinden kræver det indtagne standpunkt $\mathrm{i}$ diskussionen om Ribe domkirkes bygningskronologi en kommentar til Danmarks Kirker's opfattelse af forholdene omkring bispegravene.

Den såkaldte nichegrav i nordøsthjørnet af Ribe domkirkes nordre korsarm anses af Danmarks Kirker (s. 115) som et indirekte bevis for, at den eksisterende bygning står på forgængeren "Thures kirke“s plads. Denne påstand er interessant og fortjener nærmere overvejelse, så meget mere som behovet for at finde den nuværende domkirkes forgænger stadig eksisterer, uanset at den ikke kan kaldes Thures.

Graven, der rummer de jordiske rester af biskopperne Odinkar, d. 1043, Nothulf, d. 1140 og Asser, d. 1142, er ikke som stiftergravene i Roskilde domkirke en i selve kirkevæggen udsparet niche, men et ossuarium i form en meget korrekt efterligning af et oldkirkeligt arcosolium, opmuret og skævt anbragt i kirkevæggens murblænding; den lader sig derfor bedre end med pillegravene i Roskilde domkirke typologisk sammenligne med stifteren biskop Peder Vognsens sekundære grav i Århus domkirkes kor fra o. 1480. Man noterer sig, at Adam af Bremen nævner Odinkar som stifter af bispestolens gods, og at de to andre bisper næppe vil kunne kaldes stiftere, men at de var Thures nærmeste efterfølgere, tilsammen dog kun en fem, seks år. Arkosolgraven må være etableret efter 1142, næppe ret længe efter, at koret var rejst, dens indhold må stamme fra den ældre Ribe domkirke og overflytningen må være sket som konsekvens af dennes nedrivning og ibrugtagning af den nye bygnings kor.

Thure var den første, som byggede eller mere præcist, efter bispekrønikens ord, begyndte at lægge grunden til Ribe kirke af stentavl. I disse ord ligger underforstået, at domkirken før Thure må have været en træbygning, måske den yngste af flere sådanne på stedet, hvori Odinkar har haft sin grav. Da som tidligere her påvist "Thures kirke" må vare en fiktion forstået som en fuldført, i brug taget bygning, må også Nothulfts og Assers grave have ligget under trækirkens gulv. Men hvor kan så denne trækirke have stået? 
Rimeligvis på stedet, omend ikke nødvendigvis, hvor Danmarks Kirker har foreslået "Thures (sten)-kirke" anbragt. Det er ikke i dennes tilstedeværelse, at man skal se årsagen til højdeforskellen $i$ langhusets side- og arkademure. Det kan meget vel være den gamle trækirke "inde i stenkirken “, som har narret arkitekt og håndværkere ved afsætningen. Det har ikke været muligt at finde en eneste genanvendt sten i den nuværende Ribe domkirke. Men træ har jo også lettere ved at forsvinde sporløst end sten.

Danmarks Kirker (s. 229) har ved omhyggeligt at iagttage den nuværende domkirkes murværk kunnet konstatere, at langhusets søndre sideskibsmur er opført i tilslutning til byggeriets første fase, der omfattede korrunding og tværskib. Herved må et gulvniveau være blevet fastlagt, som viste sig at ligge $50 \mathrm{~cm}$ under det tilsvarende for nordre sideskibsmur, da dette nogen tid senere blev fastlagt. Årsagen til fadæsen kan være uagtsomhed forvoldt ved tilstedeværelsen af trækirken indenfor rammen af den under opførelse værende stenkirke. Førstnæunte kan have vanskeliggjort nivelleringen og konstateringen af det naturlige terræns, flyvesandklittens stigning mod nord. Præcist hvor trækirken har ligget under den nuværende kirke, dens midterskib eller et af dens sideskibe, er vanskeligt at afgøre. Sandsynligheden taler mest for nordre sideskib, altså tilsvarende forholdet i Lund. At Nothulf og Asser fik den ære at blive stedt til ny hvile side om side med stifteren Odinkar uden selv at have dennes høje rang, lader sig forklare derved, at deres første grave ikke lod sig respektere, da man så sig nødsaget til at sænke gulvniveauet i nordre sideskib. Det forekommer meget sandsynligt, at gulvet $i$ trækirken kan have ligget $i$ et lidt højere niveau end det omgivende terræn syd herfor, et forhold, man let kan have overset ved udlægningen af fundamentet til stenkirken. Som følge af den sænkning af gulvet i stenkirkens nordre sideskib, som fejlberegningen nødvendiggjorde, og hvorved de sidste svage spor (stolpehuller) af trækirken velsagtens er blevet fjernet, lod det sig ikke gøre at bevare bispegravene på deres oprindelige pladser; i stedet for gav stenkirkens bygherre, det vil utvivlsomt sige biskop Elias, deres indhold en ærefuld ny placering i den nichegrav, som blev muret op ad nordvæggen i det kort tid forinden rejste tværskib. Efter bortfjernelsen af den gamle, ærværdige trækirke kunne Elias' nye kor tages i brug, hvilket som af det følgende vil fremgå, først kan være sket 0.1180 . I det ydre kan Ribe domkirkes apsis have stået færdigt lidt tidligere, omtrent samtidig med Lund domkirkes i dennes ombyggede stand, måske også, som af $\mathrm{F}$. Beckett ${ }^{10}$ foreslået, i sine arkitektoniske former påvirket af denne. Ribe domkirkes apsis må betragtes som biskop Elias' værk, selvom det er blevet rejst på forgængeren Thures fundament og sokkel med anvendelse af enkelte formhuggede sten fra tiden o. 1130-40. 
Bispekrøniken oplyser intet om, hvor Thure blev begravet, derimod at Radulf, d. 1162, stedte sin forgænger Elias til hvile ved "den hellige « Liufdags side, om før eller efter dennes forhastede og ulovlige skrinlæggelse kan ikke udledes af teksten. Sandsynligheden taler for, at det er sket før. Da Radulf selv døde 1171, fik han sin grav foran Helligkors altret, der utvivlsomt traditionelt har stået $\mathrm{i}$ østenden af den nye kirkes midterskib, hvis mure på dette tidspunkt har været under opførelse. Radulfs efterfølger, Stefan, d. 1177 , blev ifølge krøniken begravet "ad australem parietem ex opposito chori“, hvorved må forstås den romanske stenkirkes, den nuværende domkirkes, søndre tværskibsarm, idet korrummet omfattede apsis og korsskæring.

Under biskop Stefan fandt så den meget omtalte brand sted, vistnok i 1176. Den egentlige årsag til ulykken ser bispekrøniken i Guds indgriben overfor Radulfs egenmægtige forsøg på at gøre Liufdag til helgen og skrinlægge hans ben, en forklaring der kan få eftertiden til at betvivle, at ulykken har varet så stor og så omfattende som beskrevet. Arkæologerne har ofte ved deres bygningsundersøgelser kunnet påvise, at de skriftlige kilder overdriver, når de beretter om middelalderens hyppige kirkebrande. Det står til troende, at kirken med klostret blev ødelagt og Liufdags ben fortæret af ilden; men ved kirken må forstås den nuværende bygnings forgænger, trækirken, som man således på et meget bekvemt tidspunkt blev af med. Til kirken kan kannikeboliger, »klostret ", have været knyttet. Det er rimeligvis ved rydning af brandtomten, at man fandt anledning til at regulere terrænet og at flytte Odinkars, Nothulfs og Assers ben til arkosolgraven i stenkirkens, nogle få år forinden opførte tværskib.

Konklusionen af disse betragtninger over Ribe bispekrønike set i forhold til den romanske stenbygning kan her til slut sammenfattes således: Den nuværende Ribe domkirke må således som af Jacob Helms, i overensstemmelse med bispekrøniken antaget, være påbegyndt opført fra øst $0.1130, \mathrm{i}$ biskop Thures tid. Rigtig gang i arbejdet kom der først under de magtfulde biskopper Elias, da domkirken fik bekræftet sine privilegier og oprettet et domkapitel 1145, og Radulf, der var kongens kansler. Branden 1176 ødelagde trækirken, men synes ikke i synderlig grad at have skadet stenkirken, af hvilken på dette tidspunkt østenden, apsis og tværskib har været højt rejst, omend endnu ikke taget i brug. Efter brandtomtens rydning, bispegravenes nyordning og terrænets regulering kunne man færdiggøre stenkirkens korparti og tage fat på at rejse det før branden delvist påbegyndte langhus. 
Ved et forsøg på at vurdere omfanget af de store kirkeværksteders indflydelse på bygningskunstens almindelige udvikling i 1100-tallets Danmark, må man erindre katedralernes umådelig lange opførselsperiode. Virksomheden er blevet afbrudt eller indskrænket på grund af kapitalmangel. Andringer (ofte forenklinger) i den oprindelige plan har af samme eller andre grunde vist sig nødvendige. Byggeværksteder er blevet opløst, andre kommet til, nye materialer bragt til anvendelse (for Ribe domkirkes vedkommende tuf fra Eifel, sandsten fra Vestfalen), tegl af hjemlig produktion, i enkelte tilfælde måske også importeret, o.s.v.

Den arkitekt ("architectus magister huius operis"), uden tvivl Donatus, som kort tid efter ærkestiftets oprettelse kom til Lund, leverede planen til den nye kirke og ledede opførelsen af dens østparti med krypten; han må være død omtrent samtidig med Asser (1137). Tyske forskere foreslår, at Donatus kan være kommet fra Speyer, hvor kejser Henrik IV (d. 1106) havde sat et stort fornyelsesarbejde igang bl.a. ved norditalienske billedhuggere. Om Lund domkirkes plan er inspireret direkte af kejserdomen ved Rhinen kan betvivles lige så stærkt som teorien om dens direkte afhængighed af anglonormannisk arkitektur. Der kan meget vel være tale om flere inspirationskilder, sandsynligst i Rhinlandet. Men ét er sikkert: Lunde-katedralens rige lombardiske skulptur optræder først efter Donatus' tid. Da kom, hvad man kunne kalde, et hold af "dekoratører" til Lund for at smykke den under opførelse stående domkirke. Hertil findes adskillige sidestykker, især i Rhinlandet fra Mainz, Maria Lach ned langs floden helt til Utrecht (denne bys nedrevne Mariakirke, 1130 'erne), der tillige med Deventer var omladningsplads for tufstenen fra Andernach (Eifel). Königsslutter, o. 1150-70 er et sachsisk modstykke til kejserkatedralerne og til Lund.

De lombardiske billedhuggere ved Lunds domkirke var fremmede fugle, som for en stund slog sig ned i det fjerne Nord, og deres indflydelse på Skånes rige skulpturproduktion, hovedsalig fonte, var mest indirekte. Gode, lettilkommelige brud af den letbehandlelige sandsten har her ligesom på Gotland været basis for oprettelsen af stenhuggerværksteder, hvis produkter, især fontene, udgjorde en fortrinlig eksportvare. Herom vidner de mange romanske stenhuggerarbejder fra Gotland, som findes på de syddanske øer fra Bornholm til Sydslesvig og spredt i danske kirker markerer den vigtige handelsrute på langs gennem Østersøen.

Bevæger man sig fra Øst- til Vestdanmark, fra Skåne til Jylland for at undersøge de romanske stenkirker og deres skulptur, er forholdet et helt andet, hvilket fremfor alt beror på de naturgivne forudsætninger: Jyllands fattigdom på brudsten egnet til byggeri. Kridtstenen på Djursland er en lokal forekomst, den porøse frådsten (kildekalk), skønt udbredt over større 
områder i Østjylland, ligeledes. Alen forekom kun brugbar til bygning i ringe mængder på Midtjyllands hedesletter. Tilbage er så blot istidens aflejringer: Den skandinaviske granit og enkelte ligeså hårde bjergarter, $\mathrm{i}$ form af vandreblokke efterladt i morænelandskabet, tættest $\mathrm{i}$ de såkaldte, nu så sjældne "stenbestrøninger«. Kun i Jylland, enkelte steder på Nordfyn og på de sydfynske øer er disse løse sten blevet forarbejdet til kvadre, brugt til murbeklædning og udnyttet til skulptur, bygningsudsmykning og inventar, især døbefonte.

Man kunne vel, negativt, udtrykke sig således, at det er manglen på tilstedeværelse af et velegnet byggemateriale, der må være årsag til, at jyderne skabte de ca. 700 granitkvaderkirker. Denne store byggevirksomhed i Valdemarstiden, o. 1150-1225 er af den tyske kunsthistoriker Richard Haupt ${ }^{11}$ kaldt den mest bemærkelsesværdige præstation, som et germansk folk har ydet i stenbygning. Bygningsforskningen har derfor også gang på gang måttet rejse spørgsmålet: er impulsen til denne præstation kommet udefra, først til domkirkeværkstederne i Viborg, Ribe og Slesvig i begyndelsen af 1100 'erne, og er kunsten at frembringe og anvende granitkvadre herfra spredt ud over hele den kimbriske halvø fra Vendsyssel i nord til Slesvig i syd, men så ikke et skridt længere, derimod, dog kun i beskedent omfang, i østlig retning, følgende de tidligere omtalte naturlige søforbindelser, men modsat den, de gotlandske fonte har fulgt.

Det synes stadig at vare vanskeligt at give et klart og entydigt svar på disse spørgsmål, som allerede Jacob Helms formulerede. Som her nævnt er det umuligt med sikkerhed at sige, hvor man i Viborg, Ribe eller Slesvig er kommet først med tilvirkningen af store granitkvadre. ${ }^{12}$

Store - indtil et par meter lange - kvadre, karmsten, tympana m.v. lader sig kun frembringe ved kilespaltning, en teknik, som romerne havde udviklet til fuldkommenhed, men som gik tabt under folkevandringstiden. Et eneste sted synes dog denne meget krævende stenbehandling at have overlevet, nemlig $i$ basaltbruddene ved Mayen vest for Koblenz, hvorfra i vikingetid udgik en stor eksport af møllesten, også til Danmark, bl.a. over Ribe. Den bløde tufsten, der i store mængder er brugt til Ribe domkirke og til landsbykirkerne på Ribeegnen, men som også ad Trene via Hollingsted blev fragtet tværs over halvøen til Slesvig, kom fra omtrent samme sted. Det er derfor nærliggende at formode, at stenhuggere fra Eifelbruddene, fortrolige med at kilespalte hårde bjergarter, kan have bragt denne tekniske viden til Jylland, da man i begyndelsen af 1100 'erne åbnede de store byggepladser i Ribe og Slesvig, og det faldt Helms naturligt at give Ribe forrangen i denne henseende. Ved den til 1140 daterede Gjellerup kirke er benyttet store veltildannede granitkvadre, hvilket klart demonstrerer, at man på dette tidspunkt fuldtud beherskede 
fremgangsmåden i Jylland. Men helt på bar bund er man næppe begyndt i Ribe og Slesvig et par årtier tidligere.

Vil man studere granitmurværk i Jylland, er Lime kirke i Salling et fremragende objekt, hvad allerede J. Helms har gjort opmærksom på. Denne kirkes skib er opført af kløvede marksten af moderat størrelse og har en nordportal, hvis dekorative former er af udpræget anglo-normannisk herkomst. Heri har man utvivlsomt med rette set en påvirkning fra England, kommet til Jylland ad søvejen gennem den indtil begyndelsen af 1100 'erne mod vest åbne Limfjord. Lime kirkes kor med de mærkelige fremspringende dyrefigurer øverst på hjørnerne og apsis er opført af, eller mere korrekt, udvendig beklædt med granitkvadre af vekslende størrelse, flest små, og muret $\mathrm{i}$ uregelmæssigt forbandt. De bevarede nederste partier af tårnet $\mathrm{i}$ vest er derimod opmuret af mere regulære granitkvadre og stammer sandsynligvis fra tiden før 1176, da kirken blev lagt under domkapitlet i Viborg. Lime kirkes østparti, kor og apsis med dens skulpturer, kan således være ligeså gammelt, måske endog lidt ældre end de jyske domkirkers kvadermurværk. Her og flere andre steder kan jyderne have eksperimenteret både som kvaderog billedhuggere. Men storværker kunne der ikke komme ud af en marksten, før man ved kilespaltning havde lært at udnytte de helt store blokke, til tympana, karmsten, søjler og fonte, og storværket inden for den jyske granitskulptur er fremfor alt Ribe kathoveddørs tympanon. Kunstforskningen har fået dette billedhuggerarbejde til at indgå i biskop Thures o. 1130 påbegyndte kirke ved at henvise til Gjellerup kirkes tympana, hvor indskrifterne ligesom $\mathrm{i}$ Ribe er anbragt langs kanten. Denne dateringsmulighed må Danmarks Kirker kassere sammen med "Thures kirke".

Efter $\mathrm{i}$ det foregående at have gjort gældende, at det var en ældre trækirke, som brændte i 1176, og at murværk fra den af Thure påbegyndte bygning stadig findes i den nuværende Ribe domkirke, må denne opfattelse også få konsekvenser for dateringen af kathoveddørens berømte relief. At dettes revner snarere skyldes forkert belastning end brand kan meget vel være korrekt (jfr. tilfældet i Nr. Brarup, Bossen, s. 82), da det som tidligere her nævnt ikke var "Thures kirke“, men trækirken, som 1176 gik op i luer. Ved forsøget på en nøjere datering af korsnedtagelsesrelieffet inddrager Danmarks Kirker indskriften, der læses således, at den, ligesom tilfældet er med Gjellerups, kan gælde synd og bod. Det forekommer overbevisende i betragtning af, at bodssakramentets symbolladede riter nøje var knyttet til kirkedøren, gennem hvilken synderen bortvistes Askeonsdag og ved reconciliationen Skærtorsdag atter blev indladt. Bogstavformerne peger efter Erik Moltkes undersøgelse på 1100 'ernes sidste halvdel; men den epigrafiske analyse har den svaghed, at materialet er så begrænset, og mærkeligt nok 
nævner Danmarks Kirker ikke, at bogstavformerne i Ribe meget ligner dem på Gjellerup kirkes tympana, hvis sikre datering på grund af indskriftens anbringelse på kanterne så ofte er taget til indtægt for den direkte sammenhæng mellem de to bygninger. Kunsthistorisk står korsnedtagelsesrelieffet absolut isoleret ikke blot $i$ Ribe, men $i$ hele landet, og hvad angår dets datering, kan 1134 ikke benyttes som nogen terminus ante quem. Det er som alle romanske tympana et teknisk uafhængigt byggeelement, derfor også uden bærefunktion (revnerne!), og kan have foreligget færdighugget et helt andet sted forinden portalens opsætning; men det kan dog også tænkes hugget $\mathrm{i}$ forbindelse hermed. På grund af transportbesvær, navnlig på landjorden, fandt grovhugning som oftest sted, hvor naturkræfterne havde efterladt råblokken, og i Jylland kan »stenbestrøninger « for en tid have været stenhuggerværksteder, ligesom af samme årsag en gruppe stendysser. Dateringen af tympanon over Ribe domkirkes kathoveddør kan næppe angives mere præcist end o. 1150 indenfor et interval på en snes år.

Hvad her er nævnt, gælder også de desværre stærkt forvitrede skulpturer af menneskeslugende løver, der bærer kathoveddørens søjler. Motivet er velkendt i Lombardiet, hvorfra det er vandret mod nord til Rhinegnene, ja helt til Lund; men i Ribe har den hårde granit påtvunget det en særegen form. Det er overhovedet karakteristisk for den jyske granitskulptur, at materialet $i$ så høj grad begunstiger enkle, i særlig lykkelige tilfælde, storladne former.

En af hjorneknopperne på Ribe Domkirkes apsissojler. (Efter Danmarks Kirker).

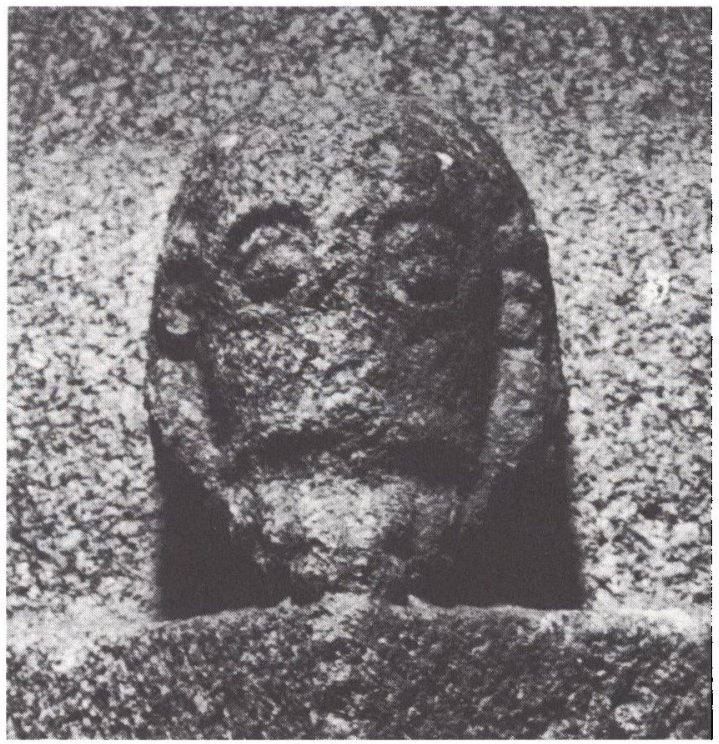




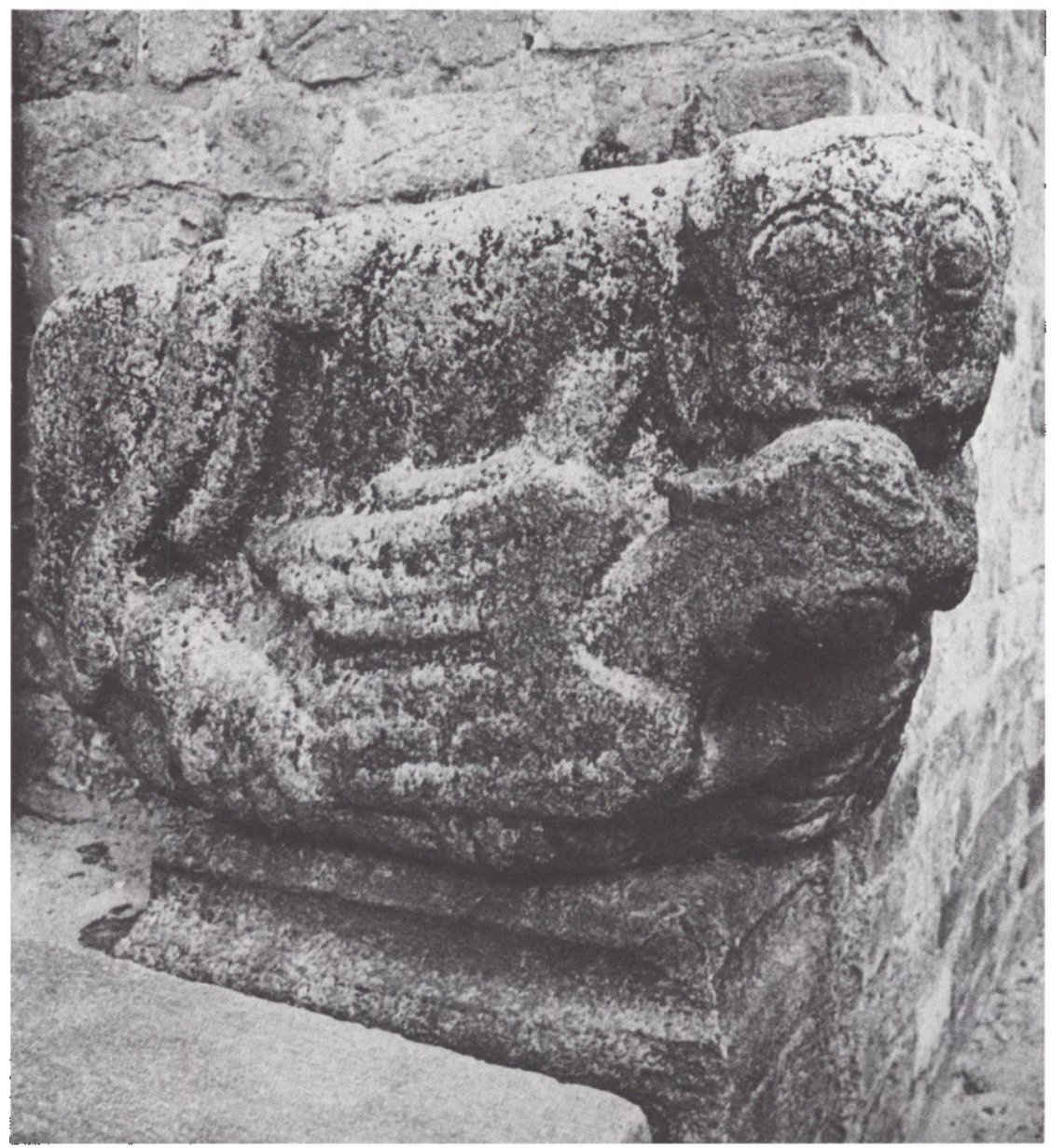

Hjernekvader pd Slesvig Domkirkes nordre tvarskib. (Efter Granit i Angel).

Skønt næsten ligeså stærkt forvitrede som kathoveddørens løvefigurer er hjørneknopperne på Ribe domkirkes apsissøjler (Danmarks Kirker, s. 202-203) mere interessante, dels fordi de som led af den imponerende sokkel må høre sammen med biskop Thures murværk fra tiden o. 1130-1140, dels fordi enkelte stiltræk, især øjnenes indramning, fremkalder erindring om Slesvig domkirkes berømte løvekvadre (Bossen, s. 19ff.), som er, og nok vedblivende vil være, gådefulde, især fordi de ikke længere sidder på oprindelig plads. Det gør derimod de to store løvekvadre, der flankerer vinduet $\mathrm{i}$ Viborg domkirkes apsissokkel længst mod øst. Disse løver af høj kunstnerisk kvalitet kan $\mathrm{i}$ kraft af deres placering dateres til begyndelsen af 
1100'erne, men de står isoleret blandt Jyllands talrige løvefigurer, ligeså isoleret som korsnedtagelsesrelieffet $\mathrm{i}$ Ribe, og de kan derfor ligeså dårligt som dette tages til indtægt for domkirkeværkstedernes betydning for skulpturfrembringelsen ude i landsognene. Heller ikke kan Slesvigløverne have haft en sådan direkte kunstnerisk befrugtende betydning. De må oprindelig have været indmuret $\mathrm{i}$ granitkvaderkirkens østparti, må derfor ligesom Viborgløverne anses for "gamle", muligvis lidt ældre end de nørrejyske rovdyr. Slesvigløverne er særlig interessante ved at være rundskulptur, men som sådan karakteristisk derved, at dyreformen ikke helt er frigjort fra den kasseformede råblok, et træk der kunne tyde på, at billedhuggeren har været uvant med behandlingen af det hårde materiale.

De senere års undersøgelser af vore domkirker bekræfter således Mackeprangs antagelse, ${ }^{13}$ at den hjemlige granit har varet taget $\mathbf{i}$ anvendelse til skulpturfremstilling ved domkirkeværkstederne i Viborg, Ribe og Slesvig i begyndelsen af 1100 'erne, muligvis tidligst, d.v.s. o. 1120, sidstnævnte sted. Hermed skal ikke være udelukket, at man hist og her i jyske kirker vil kunne påvise tympana (Skibet kirke ved Vejle f.eks.) eller fonte af ligeså stor ælde. Ved domkirkerne har dog været en overlegen teknisk sagkundskab tilstede, den helt nødvendige forudsætning for udnyttelsen af de store stenblokke ved hjælp af kilekløvning, og fra domkirkerne kan denne fremgangsmåde $\mathrm{i}$ løbet af ti-tyve år have spredt sig til de små byggepladser ude i landsognene, hvor det ikke var en arkitekt (architectus, magister operis), men blot en stenmester (lapicida), der havde ledelsen, også i henseende til, hvad vi i dag kalder det kunstneriske. En sådan praktisk uddannet mand kan ofte have fundet sine forbilleder ved den nærmeste domkirke. Således f.eks. kan søjleportalen have vundet den store yndest blandt jyder. Men også hvad angår dette karakteristiske led i den jyske kvaderstenskirkes arkitektur, er vi ilde stedt på grund af den tilstand, i hvilken de romanske domkirker er overleveret nutiden.

Af Viborg domkirkes portaler har man kun, og det ufuldstændigt, kendskab til den firesøjleportal, som sad vestligt i søndre sideskib, og som Jens Vellev (s. 5ff.) har studeret. To af søjlekapitælerne var af Wesersandsten, og, hvad formerne tydeligt afslører, fra Ribe domkirkes værksted eller materialgård. De er stærkt beslægtet med triforiesøjlernes kapitæler i søndre galleri og må af den grund dateres til tiden efter 1100'ernes midte. På dette tidspunkt har det altså været mere fordelagtigt at hente færdige skulpturdele af sandsten fra Ribe end selv at fremstille dem af granit i Viborg. Men uanset, hvorledes Viborg domkirkes øvrige portaler har set ud, skal de nok have tjent adskillige af stiftets stenmestre til forbillede.

Endnu mere sammenstykket end portalen i Viborg domkirkes søndre sideskib viser sig at have været, er Petersportalen i Slesvig, adgangsdøren til 
domkirkens søndre tværskib. Den har seks søjler, af hvilke det forreste pars skafter er af gotlandsk kalksten, og samme materiale er benyttet til nogle af kapitælerne. Petersportalens granitsøjleskafter er blankpolerede, hvad i hele den jyske granitarkitektur kun har ét sidestykke, to af kryptsøjlerne i Viborg domkirke. Fænomenet kan begge steder skyldes efterbehandling, en "oppudsning «, måske foretaget lang tid efter søjlens opstilling.

Petersportalens ofte omtalte tympanon er udført af rødlig sandsten fra Skåne, hvor dets fladhugne relief, der viser en fremstilling af Kristi overdragelse af nøglemagten til Peter og loven til Paul ("Traditio legis «), med den kongelige stifterfigur kan være blevet til. Kongefiguren lader sig mest sikkert identificere med Valdemar I, der o. 1175 skænkede biskop Frederik den halve Slesvig mønt og en del af sit gods. Herpå fulgte så 1187 Knud 6.'s store immunitetsprivilegium.

Petersportalen i Slesvig er ofte blevet javnført med kathoveddøren i Ribe, hvilket har mere historisk end kunsthistorisk rimelighed for sig, navnlig efter at sidstnævnte er blevet suppleret med det såkaldte trekantsrelief (Danmarks Kirker, s. 222f). Dette omfangsrige billedhuggerarbejde af Wesersandsten betegner sig selv som en fremstilling af "Civitas Hierusalem " og viser under Mariafiguren en kongeskikkelse, som Danmarks Kirker identificerer med Valdemar 2. Kongefiguren i Slesvig kan med sikkerhed opfattes som stifter, hvilket utvetydigt fremgår af den kirkemodel, han rækker op til Kristus. Ribe-kongen på trekantrelieffet ses at modtage et kors fra Jomfru Maria, der her symbolsk er at forstå som Jesu brud, kirken. Dette bestyrker opfattelsen af, at denne kongefigur skal forestille Valdemar 2., der i 1215 "tog korset « og af paven blev anerkendt som korsfarerkonge. Relieffet må være blevet til ca. 1220. ${ }^{14}$ Men Danmarks Kirker opfatter (s. 225ff.) kongens kors som symbol på en bøn, der rettes til Maria og gør således relieffet til epitafium.

I den nedre del af Slesvig domkirkes søndre tværskibsarm består byggematerialet ligesom i Ribe domkirkes ældre partier af granit og tuf, i den øvre af teglsten, og portalen kan være indsat, da man havde opgivet den besværlige kvadertilvirkning til fordel for teglbrændingen, der fra $0.1160 \mathrm{i}$ stor målestok var sat igang ved opførelsen af de store sjællandske klosterkirker og - vel omtrent på samme tid - af Valdemarsmuren på Danevirke, altså i kort afstand fra Slesvig domkirkes byggeplads. Hermed er berørt et vigtigt problem: Forholdet mellem kirkebyggeri af brudsten (i Jylland granit) og teglsten, et problem, der ikke er tilstrækkeligt grundigt behandlet og heller ikke kan blive det her, skønt det ingen steder trænger sig stærkere på end omkring Slesvig.

Udfra vor tids materialistisk-teknologiske betragtning ville det være 
naturligt at antage, at indførelsen af en "ny « teknik som teglbrænding hurtigt måtte have slået de ældre materialer af marken, især granitkvadrene, der var besværlige at fremstille og at bruge. Men teglstenen, som straks blev en succes ved de store klosterbyggerier, gjorde sig forholdsvis sent gældende på domkirkernes da forlængst etablerede byggepladser, og synligt kun i Viborg og Ribe domkirkers vestfronter, hvor teglsten stødte sammen med granitten i portalerne, således som tilfældet også er ved den kgl. patronatskirke, nu kaldt Vor Frelsers kirke i Horsens, en senromansk pseudobasilika, der som sådan og ved sin vestportal viser afhængighed af Ribe domkirke. Men i det lange løb slog teglen den jyske bygningsskulptur af marken, og hvad der i Danmark, bortset fra Skåne, er frembragt af romansk bygningsskulptur ud over den jyske granit, er næppe værd at nævne.

Bogen Granit i Angel behandler en lille, egnsbundet gruppe monumenter, men så kyndigt og på så bred en baggrund, at denne bog, hvis billeder og tekst så smukt følges ad, side over for side, lader sig bruge som indføring i hele den jyske granits store og spændende verden, også dens idéverden. Og måske er det $\mathrm{i}$ denne, at vi skal søge forklaringen på jydernes halsstarrige vedholden ved granitten.

Det antages almindeligt, også af Jane Bossen, at kirkerne i Sørup, Munkbrarup, Husby og Nr. Brarup, i visse henseender også Ulsnæs kunstnerisk står i gæld til domkirken i Slesvig. Forskerne har til støtte for denne antagelse især henvist til søjleportalerne, både hvad angår deres arkitektoniske type og skulpturudsmykning.

Man kan i almindelighed undre sig over, at jyderne så længe, et godt stykke ind i 1220 'erne, vedblev at tildanne marksten til kvadre og forme dem til skulptur. Her i vor sammenhæng må vi nøjes med at se lidt nærmere på slægtsforholdet mellem Slesvig domkirke og kvaderstenskirkerne i Angel.

Også i denne forbindelse trænger dateringsproblemet sig stærkt på. Angels kvaderstensbygninger anses traditionelt for "sene «, dvs. fra tiden 0.1200 . Til støtte for denne antagelse henvises gerne til bygningernes høje rejsning og til lighedspunkter inden for det skulpturelle område med domkirkens Petersportal. Unægtelig er især Sørup kirke, den ypperste af dem alle, høj og flot, hvilket måske skyldes, at den fra første færd kan have været kongeligt patronat. Det spidse tag kan dog ikke bruges som argument for den oprindelige bygnings sene datering. Men kirkens nordportal virker både ved sin anbringelse i et murfremspring og ved tympanons nøglemagtssymbol som en beskeden efterligning af Petersportalen. I skulpturformerne leder man dog forgæves efter lighedspunkter. Det er en meget folkelig stenmester, der her nok har set på domkirken, men i øvrigt fuldkommen selvstændigt udfoldet sit 
frodige, uskolede billedhuggertalent. Hans figurer har slet intet at gøre med domkirkens løveskulpturer, og Petersportalen kan som nævnt ikke bevidne, at der så sent i 1100'erne har været knyttet et billedhuggerværksted til Slesvig domkirke. Sørup kirke synes at være et eksempel på, hvorledes afhængighedsforholdet som oftest har været, også i Nørrejylland: Domkirkeværkstedet kunne levere forbilleder og teknisk viden til en lokal håndværker, der på en gang var stenhugger (lapicida) og stenlægger, murer (murator, caementarius), det vi som oftest på dansk kalder en stenmester og regner for en kunstner. Størsteparten af den jyske granitskulptur må bedømmes som folkekunst, udslag af en frodig formglæde, der frimodigt sprænger de klassiske normer og derfor også i enkelte lykkelige tilfælde hæver sig til det helt usædvanlige, således to steder i Angel, i Ulsnæs og Munkbrarup.

De skulpturer, som pryder den stærkt ombyggede Ulsnæs kirke, en bygning af kløvet kamp og tuf (langt mod øst, men tæt ved Slien!) står domkirkens så nær, at Jane Bossen (s. 35) med rette i dette tilfælde regner med en direkte forbindelse. Ganske særlig smukke er "Det omfavnende par" (s. 39) og hjørnekvadren "Havmanden og akrobaten" (s. 41), smukke på grund af figurernes bløde, runde former og rolige, rytmiske samspil. Men svært er det at tage stilling til, om mesteren er kommet fra et større professionelt værksted, eller om han blot i et sådant har lært et håndværk. Ligeså vanskeligt er det at tolke Ulnæskvadrenes billedsprog; Jane Bossen forsøger forsigtigt og velovervejet. Sydportalens tympanon med Kains og Abels ofring som skulptur er et sjældent eksempel på den store betydning, som middelalderens exegeter tillagde typologien. Relieffet viser, hvorledes de to gammeltestamentlige skikkelser rækker deres ofre op til den tronende Kristus, kendbar ved korsglorie og bog (evangeliar). Således er dette billede en tydelig henvisning til messeofret, og man kunne have forventet det anbragt $i$ korbuen. Men under alle forhold er der god mening $i$ at pryde kirkedøren med billedet af den tronende Kristus, al den stund Kristus kalder sig selv døren (Johs. 10,9), og nøglemotivets yndest beror på, at Peter, og efter ham kirkens biskopper, fra Kristus har modtaget magten til at løse og binde (Matth. 16,19).

Når som tidligere næunt Ribe domkirkes kathoveddør et halvt århundrede efter portalens opmuring blev suppleret med det store relief af det himmelske Jerusalem, har denne placering sin teologiske begrundelse ved henvisning til Johs. 10,9; både Sicardus (d. 1215) og Durandus (d. 1296) tolker kirkedøren (Kristus) som indgangen til det himmelske Jerusalem, hvortil Jesus har åbnet adgangen, jfr. Brevet til Hebræerne 12,22-24, hvis ord helt direkte må have inspireret Ribe-relieffets billedhugger. Dette og endnu et bibelord kan have stået at læse på det øverste par engles nu tomme skriftbånd, der synes at være 
udplanede ved efterhugning, en behandling, som i det hele vanskeliggør en stilhistorisk bestemmelse af det store billedhuggerarbejde.

Sidste halvdel af Granit i Angel er viet omtalen af egnens døbefonte og en sammenfatning på tysk af hele bogens indhold. Indledningsvis erindres om, at der i middelalderen fandtes specielle fonteværksteder, som ikke blot arbejdede for at tilfredsstille et lokalt behov, men for eksport. En af Gotlands pragtfuldeste fonte er endt i Sørup. To af granitfontene i Angel (Grumtoft og Hyrup) har taget vejen fra det såkaldte "Horder-værksted " på Djursland, velsagtens sammen med den mørtel, som fandt anvendelse ved opførelsen af Kong Valdemars mur på Danevirke, måske også af Slesvig domkirke. Men langt mere interessant end Horders sirligt huggede fonte er de figurrige $i$ Husby og Munkbrarup. Førstnæunte udmærker sig ved et klart teologisk billedprogram, der sætter menneskets syndefald over for dets forløsning ved korsofret (Rom. 6,4), Adam overfor Kristus. Hertil er føjet en advarsel mod vellysten. Djæuleuddrivelsen var et vigtigt led $\mathrm{i}$ dåbsritualet. Det skal $\mathrm{i}$ parentes bemærkes, at spydbæreren Longinus ikke græmmer sig, men peger på sit øje, der ramt af en dråbe af Frelserens blod gjorde den romerske soldat, den kristne ridders "arketype ", seende, dvs. troende. Jane Bossen spørger s. 42, hvad en ridder som Satrup-relieffets meget elegante figur har at gøre på en kirkemur. Den kristne ridder kan også her være symbol på fortitudo, åndelig styrke eller tapperhed, en højt værdsat kristelig dyd.

Munkbrarups kirkes herlige granitfont er lige usædvanlig ved sin form og sin forkyndelse, hvor svært end nutiden kan have ved helt at forstå dens symboler. Hvad især gør denne font interessant er forholdet mellem brugstingens abstrakte form (karret) og udsmykningen. Stenhuggeren har utvivlsomt ladet sig inspirere af et metalkar understøttet af tolv ben, tolvtallet er afgørende, jfr. kobberkarret i Templet (1. Kongebog 7,25). Påfaldende ved Munkbrarupfonten er, at mesteren ikke har holdt sig til at reliefgive kummens sider, men ved udformningen af sit hovedmotiv: Kampen mellem mennesket og løven, ladet den overfaldne stå på fontens fremspringende plint, således at figuren fra hoftehøjde og nedefter er næsten frigjort fra dåbskarret og fejlagtigt kan virke svævende. Dette er et dristigt, også helt usædvanligt træk. Jane Bossen kritiserer med rette tidligere forskeres opfattelse af den kongefigur, der med velsignende oprakt højre hånd $\mathrm{og}$ opadvendt sværd $\mathrm{i}$ venstre indtrængende henvender sig til beskueren fra sin borgs tinde. Forfatteren henviser til Christus majestatis-motivet. Det vil, uden dog her at se problemets endelige løsning, $i$ den forbindelse være naturligt at minde om den hymne, der blev sunget ved dåbsvandets indvielse påskelørdag nat: Rex sanctorum angelorum, De hellige engles konge. Den er fra Slesvig stift bl.a. overleveret i Notmark manualet fra 14. århundrede. ${ }^{15}$ 


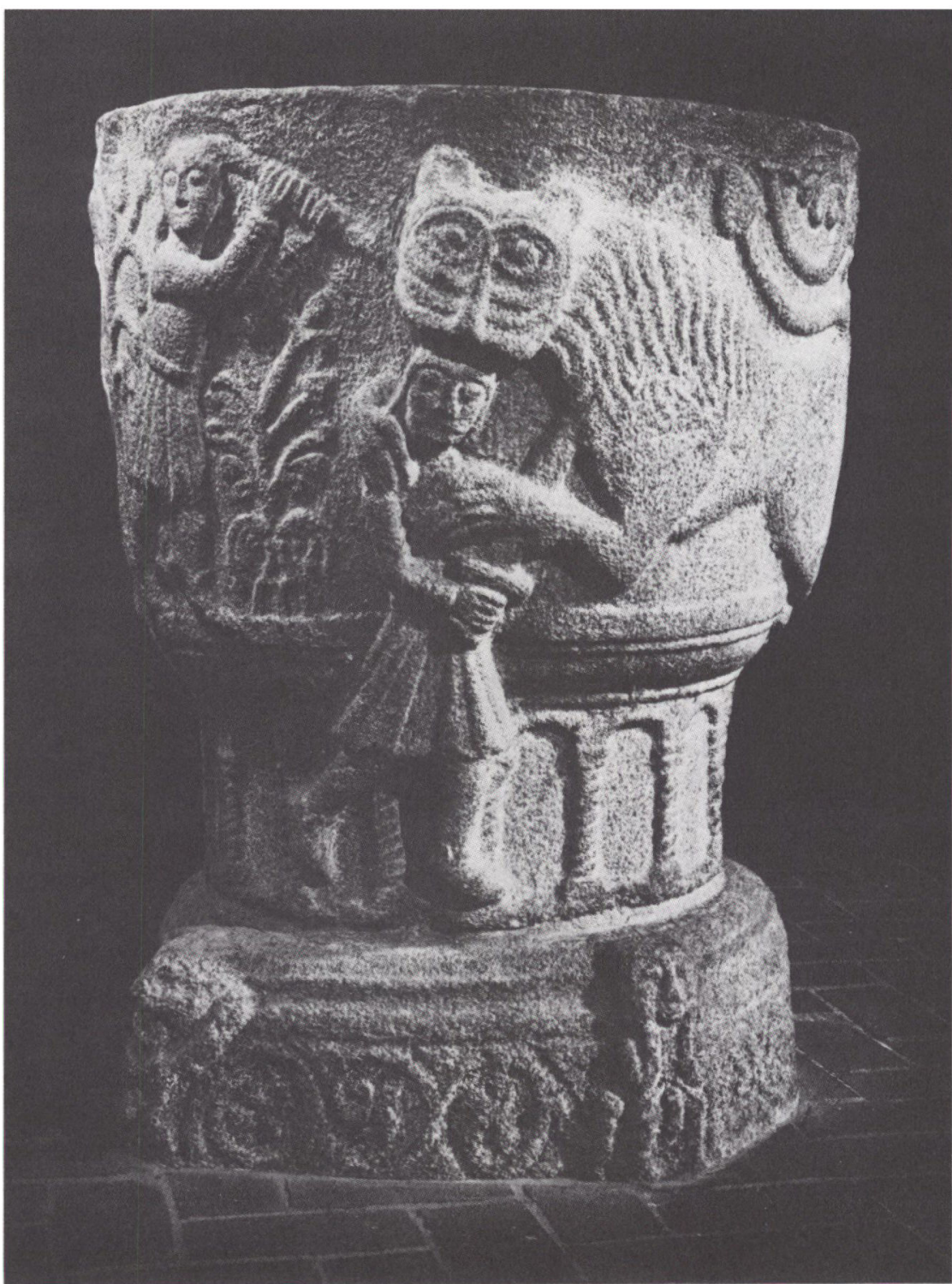

Kampscene fra Munkbrarup kirkes debefont. (Efter Granit $i$ Angel).

Majestatsfigurens attribut er dog ufravigeligt evangeliaret (jfr. tympanon fra Ulsnæs), men Guds Ord tolkes ofte i middelalderen symbolsk som Åndens sværd (Efeserbrevet 6,17). Tager man middelalderens allegoriske fortolkningsmetode $\mathrm{i}$ anvendelse, kan Munkbrarupfonten give stof til en hel 
afhandling, og, hvad tidligere blot blev anset for drolerier, finde forklaring i en meningsfyldt liturgisk sammenhæng, således for eksempel den siddende mandsfigur på plinten (s. 55), hvis fallos, avlekraftens tegn er symbol på den andelige styrke fortitudo, en af de fire kardinaldyder. Tallet fire har sin særlige betydning: De fire evangelier, de fire verdenshjørner, paradisfloder m.v., og med disse er døbefonten, således som den oprindelig må have været opstillet $i$ kirkens skib, i meningsfuld sammenhæng med det kristne kosmos og med dåben. Den lille fallosfigur, der afbildes s. 55 i Granit i Angel, har en ligeså udtryksfuld kollega på helsidebilledet s. 32, der viser kraftkarlen bære en søjle i Nr. Brarup kirkes portal ligesom tilfældet er med en yngre broder i Ribe domkirkes midterskib (Danmarks Kirker, fig. 162), hvis byrde er en af hvælvingernes gjordbuer. Men et så karskt symbol på den styrke, som holder kirken oppe, tænkte den viktorianske tid ilde om. Ribe-manden blev 1865 skamferet og ærbart iført et par gymnastikbukser.

I det foregående er givet et par eksempler på, hvorledes billedtolkningen kan drage nytte af den allegoriske skriftudlægning. Metoden har ikke blot gyldighed overfor tekst og billeder, men lader sig også tage i brug overfor selve kirkebygningens naturgivne materialer og dens rent arkitektoniske former. Dette skal her til slut erindres $\mathrm{i}$ forbindelse med spørgsmålet: Hvorfor gjorde jyderne sig så store anstrengelser for at bygge kirker af granitkvadre?

Som nævnt havde istiden også været gavmild med stenlevering til øerne, men sjællænderne lod sig nøje med at håndkløve de mindre og sparede sig således for kiling og udglatning. Det er en gammel vittighed, givetvis af jysk oprindelse, at årsagen skal søges i sjællændernes dovenskab. Vittigheden bliver dobbelttydig, når man tager i betragtning, at de sjallandske kirker af rå kløvet kamp har vist sig at være langt solidere end de fine jyske kvaderstensbygninger. At disses ydre murskal næsten altid har måttet sættes om, skyldes netop, at materialet var så glat og fint. Indvendig blev kvadrene sjældent brugt til andre dele af murværket end triumfmuren, der var ganske særlig betydningsfuld, fordi den afgrænsede det allerhelligste, korrummet med højalteret. Der er i denne anvendelse et fingerpeg i retning af, at de så fint tildannede sten blev tillagt en særlig betydning $i$ åndelig henseende, og at jyder, når det kom til stykket, ikke var flittigere, men muligvis frommere end øboerne.

Vi må under sådanne overvejelser helt se bort fra vor egen tids æstetiske betragtninger og derfor finde det ligegyldigt, hvor skøn vi umiddelbart anser en kvaderstensmur at være. Sagen drejer sig om middelaldermenneskets syn på det skønne, derfor har også i denne sammenhæng "sensus allegoricus “ gyldighed, som anvendt på kirkebygningen er lettest tilgængelig gennem 
Joseph Sauers berømte bog. ${ }^{16}$ Forfatteren henviser heri til periodens liturgiske forfattere, især Honorius Augustodunensis, der om bygningsstenen udtaler, at den helst skal være firkantet. Om middelalderens talmystik, in casu firetallet er ovenfor lige ytret et par ord. Samtiden benæunte murværk af sådant formede sten, kvadre for "structura quadrata ", hvad i Frankrig i 1100-tallet var gået af mode; her kaldtes det "le grand appareil “. Liturgikerne siger videre, at kvaderstene er menneskene i fuldkommenhedens højere stand, som ved fortjeneste og bøn holder kirkens svagere led sammen. Med disse eksempler står vi overfor et vigtigt princip i middelalderens opfattelse af (bygge-)materialet, nemlig at dette ved tildannelse, finhugning, polering o.l. forøger sin sjælsopløftende (anagogiske) egenskab. Man kan derfor, udfra en historisk betragtning af det skønne, værdsætte de så fint tilhugne granitkvadre og samtidig undre sig en smule over, at et historisk museum, Nationalmuseet, nylig har kunnet finde på at lade vore lueforgyldte romanske alterprydelser virke på en skærmvæg af rå stenfliser. Brutalisme er ikke middelalderens skønhedsopfattelse.

Den jyske granit kan ikke være udtryk for, at den nøgne kvinde har lært sig at spinde, ihvertfald ikke udelukkende dette. Ej heller lader kvaderstenskirkerne sig tage til indtægt for overlegen teknisk formåen, $i$ så fald ville jydernes façadekvadre ikke have haft omsætning behov. Hvis man har svært ved at forestille sig en særlig stor folkefromhed nord for Ejderen og vest for Lillebælt, må forklaringen på kvadermurværket og den hermed sammenhørende granitskulptur være flerfoldig og bero på et folkegeni, som ydre naturgivne og historisk betingede omstandigheder bragte til frodig udfoldelse. Heraf fremgik værker, som eftertiden ikke kan blive færdig med at glæde sig over og at forske i. Danmarks Kirkers hefter om Ribe domkirke, billedværket Granit i Angel er nye vidnesbyrd herom, to veltilhugne kvadre i lærdommens mur, som her er poleret lidt på.

\section{NOTER}

1. M. Mackeprang: Vore Landsbykirker. En Oversigt. Kbh. 1920, (2. udg. 1946).

2. Danmarks Kirker. Udg. af Nationalmuseet. Ribe amt ved Elna Meller under medvirken af Ebbe Nyborg, 1. bd. Nationalmuseets Forlag. Kbh. 1979 fl. forkortet DK.

3. Die Kunstdenkmäler der Stadt Schleswig II. Der Dom und der ehemalige Dombezirk. Bearbeitet von Dietrich Ellger, unter Mitwirkung von Johanna Kolbe, Rudolf Zöllner und Susanne Lücke-David. Deutscher Kunstverlag 1966. Her forkortet Ellger.

4. Jens Vellev: Viborg Domkirke. Artikler fra tidsskriftet Skalk. Forlaget Hikuin. Århus 1981. Endv. Middelalderstudier I. Viborg Stiftsmuseum. Viborg 1970.

5. Erik Cinthio: Lunds domkyrka under romansk tid. Lund 1957.

6. Jane Bossen - Helge Krempin: Granit i Angel. Studieafdelingen ved Dansk Centralbibliotek for Sydslesvig. Flensborg 1980. Her forkortet Bossen. 
7. Motet-Dechamps: Receuil de textes II, Paris 1929, s. 158.

8. Dr. Jacob Helms og prof. H. C. Amberg: Ribe Domkirke. I Anledning af Kirkens Hovedistandsattelse 1882-1904. Kbh. 1906.

9. Hugo Johannsen, i Danmarks Arkitektur. Kirkens huse. Kbh. 1981, s. 29.

10. Francis Beckett: Danmarks Kunst I. Kbh. 1924, s. 74.

11. Repertorium für Kunstwissenschaft 1925.

12. Otto Norn: Jydsk Granit. Kbh. 1968, s. 10ff. Knud Høgsbro Østergaard: Kvaderstensteknik, i Aarbøger for nordisk Oldkyndighed og Historie. Kbh. 1962. Jfr. smstds., 1954, O. Norn: Det grumme Dyr fra Skibet, s. $208 f$.

13. M. Mackeprang: Jydske Granitportaler. Kbh. 1942, s. 331.

14. O. Norn: At se Det usynlige. Kbh. 1982, (under udgivelse).

15. Erling Rump: Inskriptionen pả Øster Hornum fonten, i Fra Himmerland og Kjær Herred 1972. Heri andre eksempler på sammenhæng mellem dåbsritualer og fonteudsmykning.

16. Symbolik des Kirchengebäudes und seiner Ausstattung des Mittelalters 1902, 2. udg. 1924. Det er videnskabshistorisk ganske interessant at konstatere, hvor ringe betydning Sauers værk havde for den positivistiske kunstforskning således som i Danmark repræsenteret af M. Mackeprang og P. Nørlund. Først da Panofsky-skolen o. 1930 havde vakt kunsthistorikernes interesse for ikonologiens problemer, fik middelalderens liturgikere en indflydelse på fagets forståelse af middelalderkunsten, som er $\mathrm{i}$ overensstemmelse med denne periodes begreb om Det skønne. 
